\title{
The Impact of Base Lending Rate on Capital Structure in Malaysia
}

\author{
Siti Nabilah Mohd Shaari, Nik Nurul Aswani Nik Kamarudin, Suryani Abdul \\ Raman and Nurfarizan Mazhani Mahmud
}

To Link this Article: http://dx.doi.org/10.6007/IJARAFMS/v12-i1/11385 DOI:10.6007/IJARAFMS /v12-i1/11385

Received: 19 November 2021, Revised: 21 December 2021, Accepted: 27 December 2021

Published Online: 17 January 2022

In-Text Citation: (Shaari et al., 2022)

To Cite this Article: Shaari, S. N. M., Kamarudin, N. N. A. N., Raman, S. A., \& Mahmud, N. M. (2022). The Impact of Base Lending Rate on Capital Structure in Malaysia. International Journal of Academic Research in Accounting Finance and Management Sciences, 12(1), 47-62.

Copyright: (c) 2022 The Author(s)

Published by Human Resource Management Academic Research Society (www.hrmars.com)

This article is published under the Creative Commons Attribution (CC BY 4.0) license. Anyone may reproduce, distribute, translate and create derivative works of this article (for both commercial and non-commercial purposes), subject to full attribution to the original publication and authors. The full terms of this license may be seen at: http://creativecommons.org/licences/by/4.0/legalcode

Vol. 12, No. 1, 2022, Pg. 47 - 62

Full Terms \& Conditions of access and use can be found at http://hrmars.com/index.php/pages/detail/publication-ethics 


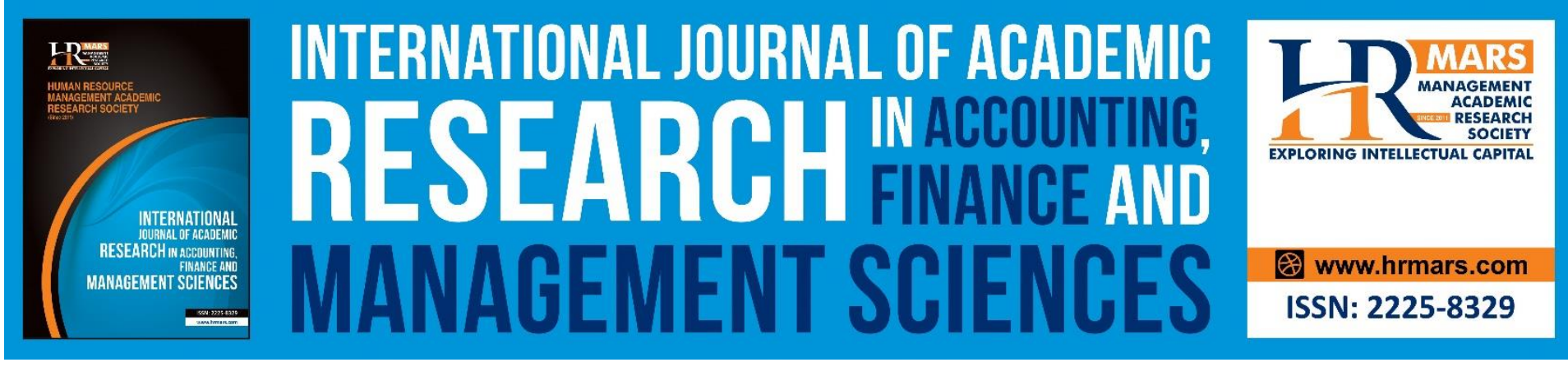

\title{
The Impact of Base Lending Rate on Capital Structure in Malaysia
}

\author{
Siti Nabilah Mohd Shaari, Nik Nurul Aswani Nik Kamarudin, \\ Suryani Abdul Raman and Nurfarizan Mazhani Mahmud \\ Faculty of Accountancy, Universiti Teknologi MARA Perak Branch, Tapah Campus, 35400 \\ Tapah Road, Perak, Malaysia \\ Email: sitin256@uitm.edu.my
}

\begin{abstract}
This paper investigates the pattern of capital structure of 4,127 Malaysian companies from 2005 to 2015. We, then specify the sample into two periods, the pre-recession period from 2002 until 2007 and post-recession period from 2009 until 2015, to determine whether there is any significant different in term liabilities between the two periods. For the third objective of this paper, we examine the impact of base lending rate (BLR) in the capital structure between pre- and post-recession periods, indicating the companies drastically change their capital structure after recession occurs. In this paper, we find a sharp downwards movement in long-term debt and total debt after 2008 year of recession. We also document the level of total debt and long-term debt to significantly higher before the recession hit. Interestingly, we find base lending rate to have negative relationship with long-term and total debts only after recession has occurred but not during the economic expansion (pre-recession period), thus supporting the study's hypotheses.
\end{abstract}

Keywords: Capital Structure, Recession, Base Lending Rate

\section{Introduction}

Exactly after a decade, the 2008 recession became the talk of the business world once more. People recollected the origin and the cause of the recession. Many believed that the recession was not a work of one person or a one-day work, but a work of different entities and individuals over a few years. The recession was initiated in United States (US) housing market, and began when the subprime mortgage loan borrowers failed to honour their obligation due to the increase in interest rates from as low as $1 \%$ to $5.25 \%$. The low interest rate was initially introduced in US with an intention to stimulate the economy after the short financial crisis in 2001, and the interest rate increased as the economy became better. However, many entities and individuals took the advantage of low interest rate and flood of liquidity to buy houses regardless of their poor creditworthiness and high risk of default. The situation got worse by the introduction of collateralized debt obligations (CDOs) which were based on the mortgage in the secondary mortgage market. The CDOs were rated inaccurately and were actively traded among investors. At one point, the demand for the houses declined 
because people cannot afford the expensive houses coupled with high interest rates. Meanwhile, the current borrowers were unable to meet their commitments as the interest rate increased which led to large amount of defaults and eventually, banks started to panic. The secondary mortgage market was shattered as well. Eventually, many were forced to file for bankruptcy and shut down the businesses. The market became very volatile which caused the investors to lose money.

Malaysia was not spared from the effect of 2008 financial crisis initiated in US as stated by the Central Bank of Malaysia (BNM) in its report, "As Malaysia is a highly open economy, the impact of the global recession was felt strongly in the external trade-related sectors. The recession in the advanced economies started to impact the Malaysian economy in the fourth quarter of 2008." (Central Bank of Malaysia, 2009, p. 13). However, unlike US, the impact of the recession was different in Malaysia. At the time US was hit by the 2008 recession, the Malaysian banking system was sturdy, the financial market was able to absorb the shock, and the country's reserve was strong to face the crisis as the lesson was learnt during the Asian Financial Crisis 1997 - 1998 (Central Bank of Malaysia, 2009; Prema-chandra, 2010). Malaysians also had little exposure to the CDOs which were introduced in US. Even though the financial market was reported as performing good, Prema-chandra (2010) mentioned that there is a huge drop in the KLSE Price for 2008 approximately 20\% between 2007 and 2009. Deesomsak, Paudyal and Pescetto (2004) studied the difference in the capital structure between pre- and post- Asian Financial Crisis 2007 of Asian Pacific Region countries, specifically, Thailand, Malaysia, Singapore and Australia. At that moment, the reduction in share price was around $30 \%$. They concluded from their findings that recession had significant impact on the capital structure. For example, in the case of Malaysian firms, the factors contributing to the choice of capital structure were different between before and after recession. Some of the factors, such as firm size, growth opportunities, non-debt tax shields and liquidity, became significant after the recession.

\section{Capital Structure Determinants}

Aside identifying the determinants from the capital structure theories (tax deductibility, transaction cost, financial distress cost and profitability), they can also be are discovered through empirical researches (firm-specific, institutional and country-specific factors). Prior literature has shown evidence that the firm specific factors such as profitability, firm size, asset tangibility, growth opportunities, and non-debt tax shields are significant determinants of capital structure.

The significant negative relationship between profitability and debt (Booth et al., 2001; Deesomsak et al., 2004; Fama \& French, 2002; Fraser, Zhang, \& Derashid, 2006) is as predicted by pecking order theory which asserts that the highly profitable companies tend to finance investments with retained earnings rather than using debt or equity. The finding, however, indicates the important failure of trade-off theory (Fama \& French, 2002) which predicts a positive relationship. In the case of developing countries, the negative relationship could be due to problems of undeveloped nature of the capital market and information asymmetry (Booth et al., 2001).

Firm size and debt, which are positively related as found by most studies (Booth et al., 2001; Deesomsak et al., 2004; Frank \& Goyal, 2003; Fraser et al., 2006), conforms to the prediction of trade-off theory. It indicates that the larger firms tend to diversify and fail less often, thus have bigger capacity to use more debt. However, some studies find a negative 
relationship between firm sizes and leverage, which means, the small firms tend to rely heavily on bank loans due to their limited access to the equity capital market (Chen, 2004).

Regarding asset tangibility, most evidence shows a positive relationship with debt (Cheng \& Shiu, 2007; Deesomsak et al., 2004; Frank \& Goyal, 2003; Hirota, 1999) because tangible assets are easy to collateralise for debt (Chen, 2004) and collateral reduces default risk for lenders (Suto, 2003).

As expected in trade-off theory, a negative relationship is found between growth opportunities and debt (Booth et al., 2001; Fama \& French, 2002; Frank \& Goyal, 2003; Pandey, 2001) because firms with many growth opportunities tend to be riskier due to large costs of financial distress (Hirota, 1999) and the difficulty of borrowing against intangible growth opportunities (Booth et al., 2001).

Trade-off theory also suggests a positive relationship between debt tax shield and debt. However, instead of using debt to take advantage of reduction in tax, the firms also can lower their tax by subtracting non-debt tax shields, such as, depreciations, selling and general administrative expenses and research and development costs. Therefore, a negative relationship between non-debt tax shields and debt is expected, and is confirmed by previous studies (Deesomsak et al., 2004; Fama \& French, 2002; Wiwattanakantang, 1999; Zou \& Xiao, 2006).

In addition to the common firm-specific factors, the previous studies also investigated the effect of corporate governance on debt, particularly, the firm's ownership. The firms usually use debt to mitigate the agency problem between the shareholders and the management of the firms. Hence, it is expected that highly concentrated ownership firms have lower debt than low concentrated ownership firms do, and Miguel and Pindado (2001) and Suto (2003) confirmed the expectation in their study. Suto (2003) also found that foreign ownership helps to monitor corporate management's actions. In Malaysia, the debt of firms with political connection is higher than the firms without the political connection (Ebrahim et al., 2014; Fraser et al., 2006), especially before the period of financial crisis. Interestingly, Ebrahim et al (2014) found no significant difference after the crisis between political and nonpolitical patronage firms. However, these politically connected firms suffered the most during the crisis, which could possibly due to lose of valuable subsidiaries (Johnson \& Mitton, 2003). Similar finding was discovered for Malaysian's government-linked companies (GLCs), which also has higher debt compared to non-GLCs (Nik Nurul Aswani \& Pok, 2009). This could be due to critical differences between GLCs and non-GLCs, for instances, GLCs are infused with public funds, and GLCs have no real fear of bankruptcy as well as inequality in terms of market competition (Tselichtchev, 2007). Since the capital structure theories, which originated from United States, could not fully explain the capital structure in other countries, previous researches attempted to introduce institutional.

The development of stock or bond market, creditor or investor protection, GDP and interest rate also were found significantly related to debt. Developed bond market is found to be positively related to debt which could be due to many choices of debt instrument offered, whereas developed stock market has negative relationship with debt (de Jong, Kabir, \& Nguyen, 2008). The role of legal system to protect creditors and investors is also crucial in determining the firm's capital structure. Better creditor right protection is expected to be positively related to debt, and this is confirmed in a study of Cheng and Shiu (2007). However, de Jong et. al. (2008) found a negative relationship as they believed a tightened creditor protection signals risky debt. GDP is positively related to debt (de Jong et al., 2008) which suggested that firms are using more debt in a country with better GDP. 
In relation to recession, most of the firms were badly affected during recession as evidenced by the decline in share prices, hence, attracted many researchers to investigate the effect of recession. Few studies, however, discovered trivial change in the capital structure between pre- and post-recession periods (Ebrahim et al., 2014; Fosberg, 2008; Iqbal \& Kume, 2014; Trinh \& Phuong, 2015). Nonetheless, there were changes discovered to the relationship between leverage and firm as well as country specific factors for pre- and postrecession periods (Deesomsak et al., 2004). Also, the leverage was found increasing from prerecession to recession period (Iqbal \& Kume, 2014), and during recession, the debt accumulated (Fosberg, 2008). After recession, prior studies found the leverage and the accumulated debt were reversed to before recession (Fosberg, 2008; lqbal \& Kume, 2014)

\section{Problem Statement}

During the crisis, government and the related authorities would quickly respond to the crisis with the intention to avoid the country to slip deeper into economic downturn. Recovery policies were introduced, and different countries would take different measures. Among the measures taken by BNM during 2008 recession was money easing, i.e. reducing Overnight Policy Rate (OPR), which would affect the base lending rate (BLR) or the borrowing cost. Interest rate, which is believed to give impact to the choice of capital structure, has insignificant impact on the determination of capital structure in United States for the last forty years, but the tax rate is found to be more sensitive to firms' leverage (Karpavičius \& Yu, 2017). Bokpin (2009) discovered the same insignificant negative relationship between leverage (long-term debt) and interest rate. Interest rate is negatively related to debt and the relationship is significant only when the firms predict negative GDP. Karpavičius and Yu (2017) suggested that the firms might ignore the changes in interest rate because of its volatility, unlike tax rate which is steadier over time. Research on the impact of interest on capital structure, however, is still limited (Karpavičius \& Yu, 2017) and currently, no study in Malaysia has yet focused on the impact of base lending rate on the capital structure, distinguishing pre and port-recession periods. Therefore, following the problem statement, we have identified three research questions, which are: 1) What is the pattern of Malaysian companies' capital structure from 2002 until 2015?; 2) What is the difference in capital structure between pre and post-recession period? and; 3 ) What is the effect of base lending rate (BLR) on capital structure decision between pre and post-recession period?

\section{Research Methods}

\section{Sample Selection}

The sample includes all Malaysian public companies listed on Bursa Malaysia's Main Market. The companies chosen are from nine industries, namely, construction, consumers and products, hotel, industrial products, industry, plantation, property, technology, and trading and services. However, we exclude finance industry due to its different characteristics as well as its own unique regulations. The data for capital structure variables, specifically, TDEBT, LTDEBT, PROF, TANG, GROW, SIZE and NDTS, are collected using Thomson Reuters Eikon service. The data for BLR is collected manually from Bank Negara Malaysia Annual Reports. These variables are based on the previous literature, and they are found to influence the financing decision.

This study uses two cross-sectional data which are pre-recession period and postrecession period. We choose year 2002 until 2007 to represent pre-recession period, and year 2009 until 2015 to represent post-recession period. The reasons we exclude 2008, which is 
MANAGEMENT SCIENCES

Vol. 12 , No. 1, 2022, E-ISSN: 2225-8329 ㄷ 2022 HRMARS

the recession period (Duggal \& Budden, 2011), and do not study during recession period are because BLR is constant throughout the year and, it is applicable to all companies in Malaysia, hence, regression analysis cannot be done on one year sample.

The data are also filtered from any missing values and outliers. Accordingly, the final sample of this study consists of 4,127 companies/years observations, which consist of, 1,829 companies/years observations for pre-recession period and 2,298 companies/years observations for post-recession period. For the purpose of validity and robustness of the study, we adopt two different proxies for leverage as dependent variable. We test the hypotheses using total debts to total assets (TDEBT) in one regression model and total longterm debts to total assets (LTDEBT) in the other regression model.

\section{Hypotheses Development}

In the regression analysis, in addition of typical capital structure determinants, we add one new independent variable, which is base lending rate (BLR). BLR is the rate set by the commercial banks and it represents the cost of borrowing the money to be lent to the banks' borrowers. The commercial banks' BLRs are often determined by Bank Negara Malaysia using the overnight policy rate (OPR). The higher is the BLRs, the higher is the cost of borrowing borne by the companies.

Interest rate, which is believed to give impact to the choice of capital structure, has insignificant impact on the determination of capital structure in United States for the last forty years, but the tax rate is found more sensitive to firms' leverage (Karpavičius \& Yu, 2017). Interest rate is negatively related to debt and the relationship is significant only when the firms predict negative GDP. Karpavičius and Yu $(2017)$ suggested that the firms might ignore the changes in interest rate because of its volatility, unlike tax rate which is more steady over time. Research on the impact of interest, however, is still limited (Karpavičius \& Yu, 2017). Bokpin (2009) discovered the same insignificant negative relationship between leverage (long-term debt) and interest rate. However, a significant positive relationship is found between short-term debt and interest rate which suggested that the firms in emerging economies resort to short term financing when the interest rate increased (Bokpin, 2009).

Thus, it should signify an impact on the companies' financing behaviour, where the level of debt will be lower when BLR is increased as shown in the following hypotheses:

H1a: There is a negative relationship between BLR and total debts during pre-recession period

$H 1 b:$ There is a negative relationship between BLR and total debts during post-recession period

H2a: There is a negative relationship between BLR and long-term debts during prerecession period

$H 2 b$ : There is a negative relationship between BLR and long-term debts during postrecession period.

\section{Regression Model}

In this study, we use multiple regression analysis for our cross-sectional data, which are, pre- and post-recession periods. For each period, we run two separate regression analysis for TDEBT and LTDEBT as dependent variables. In total, we have four regression models. Figure 01 below depicts the theoretical framework for impact of BLR on the companies' leverage. 


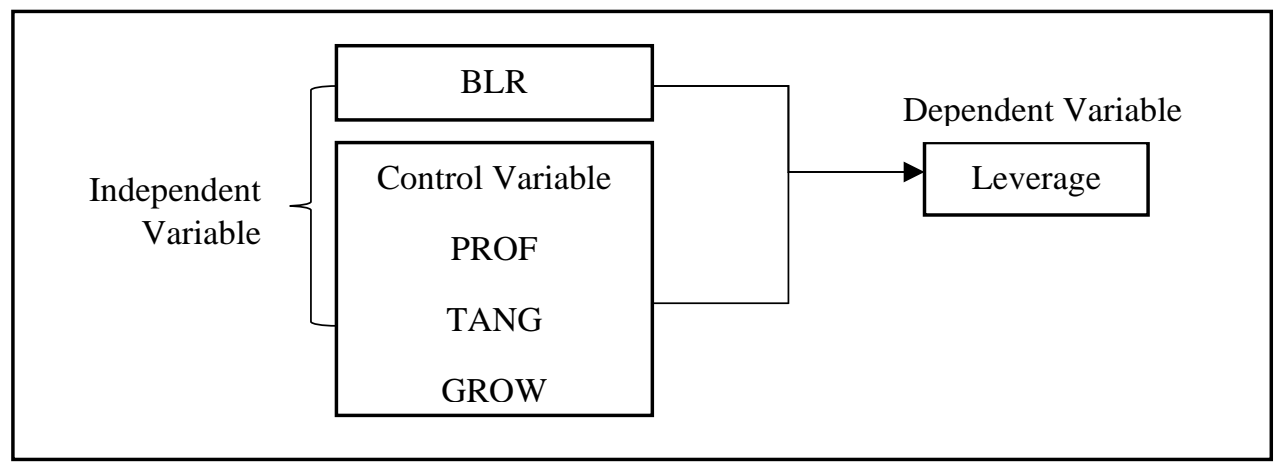

Figure 1: Theoretical Framework for Impact of BLR on the Companies' Leverage

The regression models are shown as following:

$$
\begin{aligned}
& \text { TDEBT }=\alpha+\beta 1(\mathrm{BLR})+\beta 2(\mathrm{PROF})+\beta 3(\mathrm{TANG})+\beta 4(\mathrm{GROW})+\beta 5(\mathrm{SIZE})+\beta 6(\mathrm{NDTS})+\varepsilon \\
& \mathrm{LTDEBT}=\alpha+\beta 1(\mathrm{BLR})+\beta 2(\mathrm{PROF})+\beta 3(\mathrm{TANG})+\beta 4(\mathrm{GROW})+\beta 5(\mathrm{SIZE})+\beta 6(\mathrm{NDTS})+ \\
& \varepsilon
\end{aligned}
$$

Where PROF is profitability (earnings before interest and tax/total assets), TANG is tangibility (property, plant and equipment/total assets), GROW is growth (market value/book value), SIZE is company's size (natural log of total assets) and NDTS is non-debt tax shield (depreciation and amortization/total assets).

\section{Findings}

\section{Descriptive Statistic}

Table 1 shows the comparison of descriptive analysis of samples between pre-recession period and post-recession period. Table 1 - Panel A shows the descriptive statistics for 1,829 companies/years observations from 2002 to 2007, while Table 1 - Panel B shows the descriptive statistics for 2,298 companies/years observations from 2009 to 2015. The mean for both TDEBT and LTDEBT during post-recession are lower compared to the mean during pre-recession period. This result is consistent with the finding by Jermann and Quadrini (2008) that states companies' leverage is likely to lower during the recession period. 
Table 1: Descriptive Statistics

\begin{tabular}{|c|c|c|c|c|c|c|c|c|c|c|}
\hline & \multicolumn{5}{|c|}{$\begin{array}{l}\text { Panel A: Descriptive statistics for } \\
\text { variables in pre-recession period } \\
\qquad(2002-2007)\end{array}$} & \multicolumn{5}{|c|}{$\begin{array}{l}\text { Panel B: Descriptive statistic for } \\
\text { variables in post-recession period } \\
(2009-2015)\end{array}$} \\
\hline & Min & Max & Mean & $\begin{array}{c}\text { Kurt- } \\
\text { osis }\end{array}$ & $\begin{array}{l}\text { Skew } \\
\text {-ness }\end{array}$ & Min & Max & Mean & $\begin{array}{c}\text { Kurt- } \\
\text { osis }\end{array}$ & $\begin{array}{l}\text { Skew } \\
\text {-ness }\end{array}$ \\
\hline TDEBT & 0.003 & 0.997 & 0.390 & 0.272 & $\begin{array}{c}- \\
0.495\end{array}$ & 0.005 & 0.944 & 0.371 & 0.308 & $\begin{array}{c}- \\
0.507\end{array}$ \\
\hline LTDEBT & 0.000 & 0.746 & 0.212 & 0.552 & $\begin{array}{c}- \\
0.419 \\
\end{array}$ & 0.000 & 0.733 & 0.192 & 0.603 & $\begin{array}{c}- \\
0.368 \\
\end{array}$ \\
\hline BLR & 5.980 & 6.720 & 6.362 & 0.045 & $\begin{array}{c}- \\
1.675 \\
\end{array}$ & 5.510 & 6.790 & 6.362 & $\begin{array}{c}- \\
1.287 \\
\end{array}$ & 0.396 \\
\hline PROF & $\begin{array}{c}- \\
0.108 \\
\end{array}$ & 0.228 & 0.060 & 0.099 & 0.432 & $\begin{array}{c}- \\
0.110 \\
\end{array}$ & 0.230 & 0.060 & 0.013 & 0.357 \\
\hline TANG & 0.000 & 1.444 & 0.569 & 0.254 & $\begin{array}{c}- \\
0.240\end{array}$ & 0.000 & 1.455 & 0.558 & 0.306 & $\begin{array}{c}- \\
0.655\end{array}$ \\
\hline GROW & $\begin{array}{c}- \\
0.160 \\
\end{array}$ & 2.600 & 0.934 & 0.962 & 0.572 & $\begin{array}{c}- \\
0.210 \\
\end{array}$ & 2.590 & 0.858 & 1.168 & 0.958 \\
\hline SIZE & 4.033 & 6.999 & 5.446 & 0.555 & 0.197 & 3.920 & 6.967 & 5.519 & 0.181 & $\begin{array}{c}- \\
0.347\end{array}$ \\
\hline NDTS & 0.000 & 0.364 & 0.011 & 0.838 & 0.473 & $\begin{array}{c}- \\
0.003 \\
\end{array}$ & 0.369 & 0.112 & 0.789 & 0.104 \\
\hline
\end{tabular}

Table 2 shows the descriptive analysis of the pre-recession period sample consists of 1,829 observations from 2002 until 2007 and post-recession period sample consists of 2,298 observations from 2009 until 2015. TDEBT is the total debt divided by total assets. LTDEBT is the long-term debt divided by total assets. BLR is average annual base lending rate stated and reported by Bank Negara Malaysia in their annual reports. PROF is the earnings before interest and taxes divided by total assets, whereas TANG is tangibility of assets, which defined as property, plant and equipment divided by total assets. GROW is market value divided by book value. SIZE is the logarithm of total assets. NDTS is the non-debt tax shield, which are depreciation and amortization divided by total assets.

This paper's first objective is to study the pattern of Malaysian companies' capital structure from 2002 until 2015. In Figure 2 and Figure 3, we have plotted trend analyses of annual average for total debt ratio (TDEBT) and annual average for long-term debt ratio (LTDEBT) from 2002 until 2015, with the purpose of illustrating the trend movement of companies' long-term debt and total debt.

Duggal \& Budden (2011) states that the 1998 recession effect continues until 2002, and afterward, the economy is recovered and in a non-recession period. Therefore, from 2002 to 2008, a steady trend with insignificant increase or decrease in leverage for both TDEBT and LTDEBT can be seen from Figure 2 and Figure 3. The year 2008 is recognised as the recession year and it is marked in both trend analyses. There is a sharp downwards movement, indicating a change in the financing behaviour in term of total debts and long-term debts immediately after the recession. Accordingly, the Malaysian companies reacted to the event and quickly adjusted their leverage. From 2009 until 2015, we can see the acute decline in both types of leverages before the companies slowly picking up their leverage a few years 
after the recession ended. This finding is also consistent with the study of Fosberg (2008) and lqbal and Kume (2014).

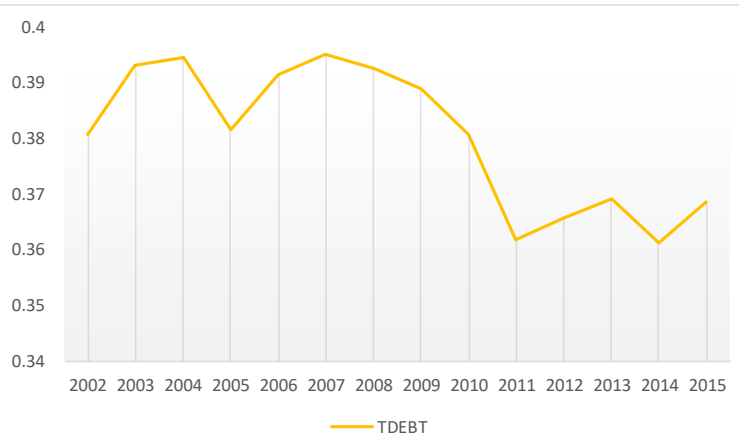

Figure 2: Trend analysis for total debt ratio

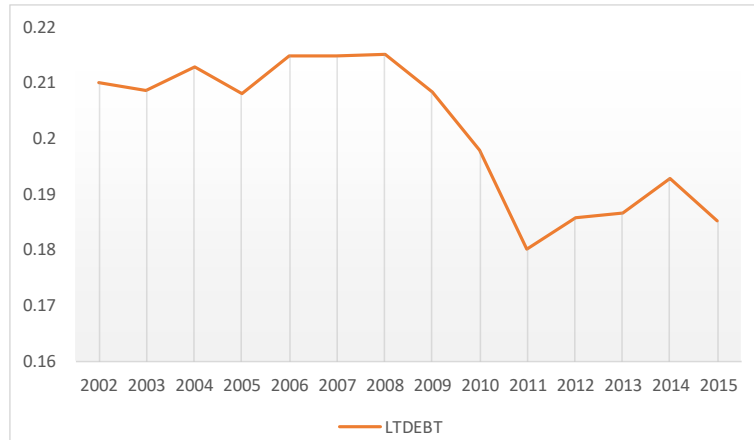

Figure 3: Trend analysis for long-term debt ratio

\section{Comparison of TDEBT and LTDEBT between pre- and post-recession period}

The second objective of this paper is to examine the difference of the companies' capital structure. Thus, we carried out the test to compare both mean of TDEBT and LTDEBT between pre-recession period and post-recession period to see whether the level of each debt is significantly higher before the recession as compared to after the recession. The results in Table 2 indicate that the TDEBT and LTDEBT during pre-recession period is significantly higher than during the post-recession period as indicated by higher mean value of TDEBT and LTDEBT, in which both are significant at $1 \%$. The results suggest that the recession does have a significant impact on the financing decisions of Malaysian companies.

Table 2: Independent t-test group statistic

\begin{tabular}{|c|c|c|c|}
\hline & $\mathbf{N}$ & TDEBT & LTDEBT \\
\hline Pre-recession period & 1,829 & 0.3898 & 0.2119 \\
\hline Post-recession period & 2,298 & 0.3714 & 0.1917 \\
\hline \multicolumn{4}{|c|}{ Independent t-test and Levene's test for equality of variance } \\
\hline & F-Value & Sig. & Sig.(2-tailed) \\
\hline TDEBT & 4.275 & 0.039 & $0.002 * * *$ \\
\hline LTDEBT & 4.279 & 0.039 & $0.000 * * *$ \\
\hline
\end{tabular}

Table 3 shows the independent t-test measurement for TDEBT and LTDEBT between prerecession period and post-recession period.

$* * *$ significant at $1 \%$

The results also suggest that the Malaysian companies borrow more when the economy is healthy and before the recession period, and significantly reduce their borrowing after the recession hit the economy. Prior studies also discovered similar findings that the companies are most likely to employ higher debts during economic growth (de Jong et al., 2008; Frank \& Goyal, 2003) and, interestingly, the base lending rate before the recession is also lower than the rate after the recession which could possibly affect the level of debt, especially between 2002 and 2005, and gradually increase up to the recession period as depicted in Figure 4. This is because, after recession, the BNM introduced the money-easing policy and the BLR is immediately reduced. Therefore, it is interesting to study the effect of base lending rate on capital structure. 


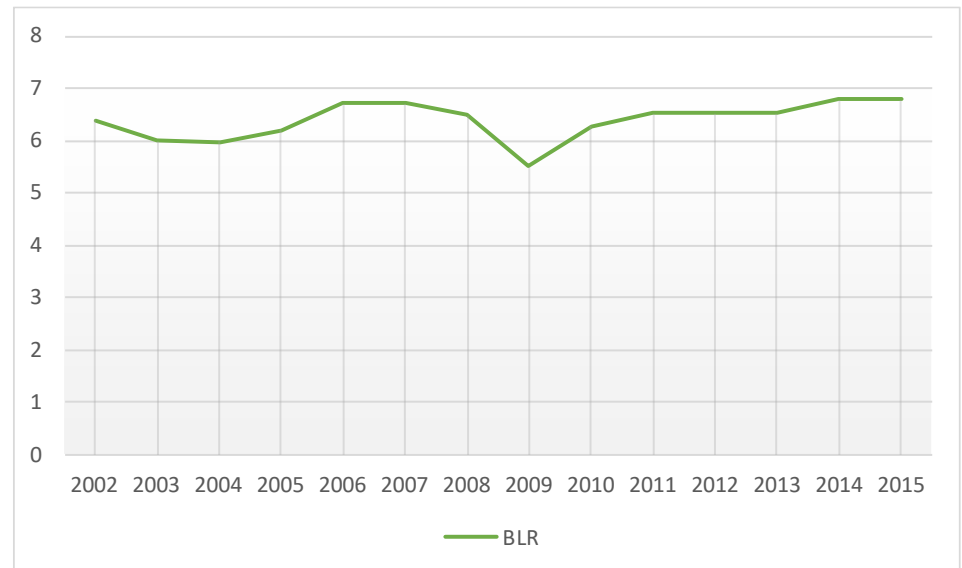

Figure 4: Trend analysis for Base-lending rate

\section{Multiple Regression Analysis}

In answering the third objective of this paper, we performed the multiple regression analysis because we have two different samples which are pre- and post-recession periods. The results are presented in Table 3 . The analysis is basically separated into TDEBT (Model 1 and 2 ) and LTDEBT (Model 3 and 4 ) as dependent variables. Then, the analysis for both TDEBT and LTDEBT are further divided into two samples for pre-recession period (Model 1 and 3 ) and post-recession period (Model 2 and 4).

Table 3 shows mix results of the impact of BLR on leverage. During pre-recession period, BLR is positively related to debt, but the result is significant at $10 \%$ only for the relationship between BLR and LTDEBT (Model 3). Hence, both hypotheses $\mathrm{H} 1 \mathrm{a}$ and $\mathrm{H} 2 \mathrm{a}$ are failed to be supported. The result is, however, the opposite of negative relationship as proposed in hypothesis $(\mathrm{H} 2 \mathrm{a})$. Possible reason is the companies tend to have higher profitability during economic expansion (N. A. Ramli et al., 2018), and hence, the companies perhaps employ higher leverage in order to enjoy the benefit from the debt tax shield which is the higher cost of borrowing due to higher BLR, on top of non-debt tax shield. Besides, since most companies have more long-term debts as compared to short-term debt, as evidenced by the difference between mean of TDEBT and LTDEBT (as seen in Table 1), the effect is more prominent when the dependent variable is long-term debts. Furthermore, Mokhova and Zinecker (2014) suggests that during expansion, companies have high profitability, and this

However, when we observe the regression result in Model 2 and Model 4 which use post-recession sample, BLR is negatively related to TDEBT and LTDEBT at significant level of $1 \%$. Our hypotheses $\mathrm{H} 1 \mathrm{~b}$ and $\mathrm{H} 2 \mathrm{~b}$ are strongly supported. The result suggests that, the companies react to the increased in BLR by decreasing the level debt accordingly, because the cost of borrowing has become more expensive. The companies' reaction to BLR is more prominent and significant after the companies experience recession. The companies appear extra cautious in making the financing decision after the recession happened, and lower the debt when GDP is not doing well (Karpavičius \& Yu, 2017) especially after the recession.

A significant and negative relationship between PROF and TDEBT is found for all regression models in this study. PROF maintains its effect on leverage during pre and postrecession. These results are consistent with the prior literature (Booth et al., 2001; Deesomsak et al., 2004; Fama \& French, 2002; Fraser, Zhang, \& Derashid, 2006) that states when a company has high internal financing, it would borrow less because it can finance their activities using cheaper source of financing which is the retained earnings. 


\section{MANAGEMENT SCIENCES}

Vol. 12 , No. 1, 2022, E-ISSN: 2225-8329 @ 2022 HRMARS

For the relationship between asset tangibility and TDEBT, it is interesting to note that before recession, TANG does not show any significant relationship (Model 1). However, after the recession, TANG is significantly and negatively related to TDEBT (Model 2). The negative relationship is as postulated by pecking order theory that a firm with more tangible assets is likely to have less information asymmetry and thereby has a greater propensity to issue equity (Zou \& Xiao, 2006). For the relationship between TANG and LTDEBT, a positive relationship is found during post-recession period, confirming our prediction. The positive relationship is also as predicted by the trade-off theory that states firms with more tangible assets has bigger ability to use their tangible assets as collateral (Suto, 2003). Regardless of the periods, our results suggest that TANG serves as collateral for long-term debt by the bank in order to reduce the credit risk. The findings found in Model 2 are also similar to the findings by Booth et al (2001) for their Malaysian sample where they found a negative relationship between asset tangibility and total debt ratio, but a positive relationship between asset tangibility and long-term debt ratio.

However, the contradiction in the relationship of TANG with TDEBT after the recession period is confounding. For LTDEBT, throughout the years, the creditors would require fixed assets as collateral for long term debt to reduce the credit risk faced by the creditors. However, the higher long-term debt acquired by the companies, the higher is the bankruptcy risk for the companies, hence, to reduce the bankruptcy costs, the total debt are lowered (Lee et al., 2000). In other words, the higher the amount of fixed assets, the higher is long-term debt. However, high long-term debt will increase bankruptcy cost, especially following the recession. Therefore, the companies, at the same time, lower its total debt in order to lower the overall bankruptcy costs. 
INTERNATIONAL JOURNAL OF ACADEMIC RESEARCH IN ACCOUNTING, FINANCE AND MANAGEMENT SCIENCES

Vol. 12 , No. 1, 2022, E-ISSN: 2225-8329 @ 2022 HRMARS

Table 3: Multiple regression analyses for TDEBT and LTDEBT

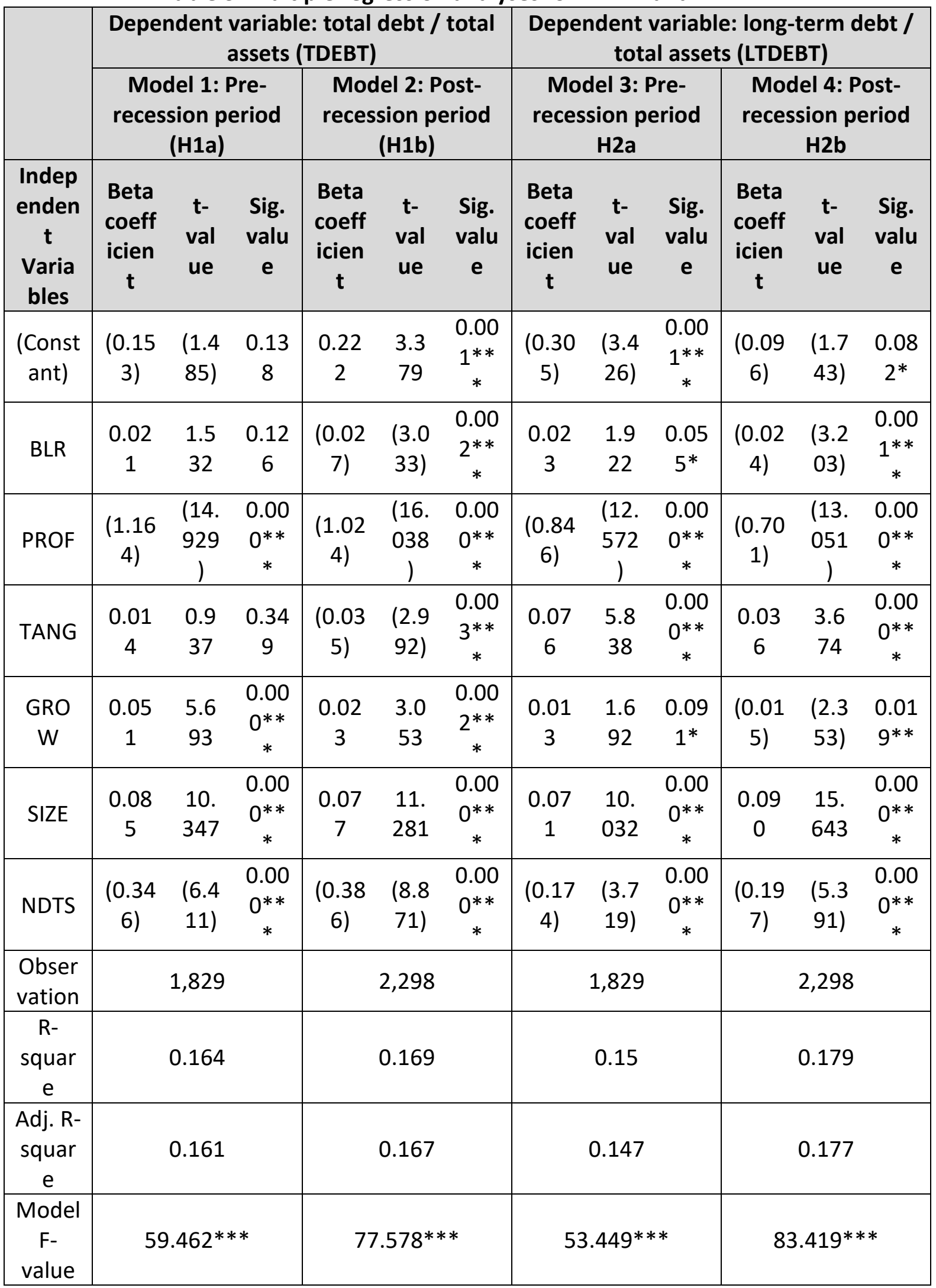

Table 4 shows the multivariate regression analysis result by using TDEBT and LTDEBT as dependent variable. TDEBT is the total debt divided by total assets. LTDEBT is the long-term debt divided by total assets. PROF is the earnings before interest and taxes divided by total 
MANAGEMENT SCIENCES

Vol. 12, No. 1, 2022, E-ISSN: 2225-8329 @ 2022 HRMARS

assets. TANG is tangibility of assets, which defined as property, plant and equipment divided by total assets. GROW is market value divided by book value. SIZE is the logarithm of total assets. NDTS is the non-debt tax shield, which are depreciation and amortization divided by total assets. BLR is average annual base lending rate stated and reported by Bank Negara Malaysia in their annual reports.

$* * *$ significant at $1 \%$

Referring to Table 3, growth opportunities (GROW) has a positive relationship with TDEBT (Model 1 and Model 2) for both periods at 1\% significant level. In addition, a positive relationship at $10 \%$ significant level is also discovered between GROW and LTDEBT before the recession period (Model 3). However, this result contradicts to previous literature (Booth et al., 2001; Fama \& French, 2002; Frank \& Goyal, 2003; Pandey, 2001) which found a negative relationship between growth opportunities and the level of debt. Only after recession period a negative relationship is found between GROW and LTDEBT (Model 4), which meets the prediction of trade-off theory. A negative relationship is predicted because high growing companies is considered high risk and hence, banks will be reluctant to extend borrowing to these companies.

The positive results found in this study, however, is as predicted by pecking order theory which states that high growth firms have greater information asymmetry that can affect the quality of the market for a firm's securities, as well as, the quality of the company projects (Zou \& Xiao, 2006). Therefore, these companies prefer to finance their projects using debt than equity. Furthermore, in Malaysia, certain industries were given the privilege to get the financing from Development Financial Institutions (DFIs), mostly bank, due to their strategic importance to the overall socio-economic development objectives of the country. Another reason is, the companies with high growth opportunities may indicate healthy business performance and thus, enabling them to finance their activities using leverage easier ( $N$. A. Ramli et al., 2018). However, this is not the case for long term debt, as the companies might face difficulty in borrowing against intangible growth opportunities (Booth et al., 2001).

The positive relationship between firm size and debt (both TDEBT and LTDEBT), at significant level of 1\%, shown in Table 3 follows the previous literature (Booth et al., 2001; Deesomsak et al., 2004; Frank \& Goyal, 2003; Fraser et al., 2006) and as predicted by trade off theory where the companies with bigger size are perceived to be more diversified and less likely to fail, which enable them to obtain debt financing easier. For both pre- and postrecession period, larger companies has advantage to obtain debt compared to smaller companies.

Lastly, Table 3 show that non-debt tax shields are significantly and negatively related to debt (both TDEBT and LTDEBT) regardless of pre- and post-recession period, at $1 \%$ significant level. The findings confirm the findings of previous studies as discussed in literature review, and the results may suggest that the higher the amount of companies' tax allowable expenses other than the borrowing cost which is commonly employed to lower the tax, the lower is the debt.

\section{Conclusion}

Recession is undeniably affected the Malaysian economy regardless of the scale of the impact. This event could alter the financing decisions of Malaysian companies and hence, the companies' capital structure. This paper, therefore, studies the pattern of Malaysian companies' capital structure from 2002 until 2015 to see if there is any fluctuation in the level 
MANAGEMENT SCIENCES

Vol. 12, No. 1, 2022, E-ISSN: 2225-8329 @ 2022 HRMARS

of debt of Malaysian companies, especially, before and after the recession. Interestingly, we have a decline in the trend after the recession compared to before recession. This finding leads to another analysis which is to examine the difference in capital structure between pre and post-recession period. The analysis confirms that the level of debt before recession is higher than the level of debt after the recession. The results suggest that the Malaysian companies borrow more when the economy is healthy but lower the debt during the economic downturn. This study believes that the change in the capital structure could be due to the lower in base lending rate as a result of recovery policies taken by the Malaysian government during the crisis.

Following that, this paper examines the effect of base lending rate (BLR) on capital structure decision. BLR is positively related to debt before the recession and negatively related to debt after the recession. The findings suggest that the Malaysian company tend to employ higher debt during good economy possibly to lower their profitability using higher borrowing cost. However, after the recession, the Malaysian companies become more cautious in employing debt when the base lending rate (BLR) is higher. The previous analysis also shows that the level of debt declining after recession. Other firm's specific variables, namely profitability, asset tangibility, growth opportunities, firm size, and non-debt tax shields, are found to be significantly related to debt as expected and concurs with the previous studies as well as capital structure theories, specifically, trade-off theory and pecking order theory. Mixed findings, however, are discovered for asset tangibility and growth opportunities between pre- and post-recession period. The findings of this study also reveal that the capital structure determinants identified from capital structure theories as well as previous literature explain the Malaysian public listed companies' financing behaviour better in the period following the recession. In addition, this study finds that base lending rate also is being considered as a determinant in the financing decision of Malaysian public listed companies.

For future study, we suggest using short-term debt as dependent variable and shortterm interest rates as the independent variables to see the effect of short-term interest against the leverage. Furthermore, the sample of the study can also be lengthened to capture two cycles of recession to see whether the results yielded will be similar or not.

\section{References}

Baskin, J. (1989). An Empirical Investigation of the Pecking Order Hypothesis. Financial Management, 18(1), 26. http://doi.org/10.2307/3665695

Bokpin, G. A. (2009). Macroeconomic development and capital structure decisions of firms: Evidence from emerging market economies. Studies in Economics and Finance, 26(2), 129-142. http://doi.org/10.1108/10867370910963055

Booth, L., Aivazian, V., Demirguc-Kunt, A., \& Maksimovic, V. (2001). Capital Structures in Developing Countries. The Journal of Finance, 56(1), 87-130. http://doi.org/10.1111/0022-1082.00320

Bradley, M., Jarrell, G. a, \& Kim, E. H. (1984). On the Existence of an Optimal Capital Structure: Theory and Evidence. The Journal of Finance, 39(3), 857-878. http://doi.org/10.2307/2327950

Central Bank of Malaysia. (2009). Annual Report 2009: How Did the Recent Global Recession Affect the Malaysian Economy? Retrieved from http://www.bnm.gov.my/files/publication/ar/en/2009/cp01_001_whitebox.pdf 
Chen, J. J. (2004). Determinants of capital structure of Chinese-listed companies. Journal of Business Research, 57(12 SPEC.ISS.), 1341-1351. http://doi.org/10.1016/S01482963(03)00070-5

Cheng, S. R., \& Shiu, C. Y. (2007). Investor protection and capital structure: International evidence. Journal of Multinational Financial Management, 17(1), 30-44. http://doi.org/10.1016/j.mulfin.2006.03.002

de Jong, A., Kabir, R., \& Nguyen, T. T. (2008). Capital structure around the world: The roles of firm- and country-specific determinants. Journal of Banking and Finance, 32(9), 19541969. http://doi.org/10.1016/j.jbankfin.2007.12.034

De Miguel, A., \& Pindado, J. (2001). Determinants of capital structure: New evidence from Spanish panel data. Journal of Corporate Finance, 7(1), 77-99. http://doi.org/10.1016/S0929-1199(00)00020-1

Deesomsak, R., Paudyal, K., \& Pescetto, G. (2004). The determinants of capital structure: Evidence from the Asia Pacific region. Journal of Multinational Financial Management, 14(4-5), 387-405. http://doi.org/10.1016/j.mulfin.2004.03.001

Ebrahim, M. S., Girma, S., Shah, M. E., \& Williams, J. (2014). Dynamic capital structure and political patronage: The case of Malaysia. International Review of Financial Analysis, 31, 117-128. http://doi.org/10.1016/j.irfa.2013.11.004

Fama, E. F., \& French, K. R. (2002). Testing trade-off and pecking order predictions about dividends and debt. The Review of Financial Studies, 15(1), 1-33. http://doi.org/10.2307/2696797

Fama, E. F., \& French, K. R. (2004). The Capital Asset Pricing Model : Theory and Evidence. Journal of Economic Perspectives, 18(3), 25-46. http://doi.org/10.1257/0895330042162430

Fosberg, R. H. (2008). Capital structure and the financial crisis. Journal of Finance and Accountancy, 11, 46-56. Retrieved from www.aabri.com/manuscripts/121213.pdf

Frank, M. Z., \& Goyal, V. K. (2003). Testing the pecking order theory of capital structure. Journal of Financial Economics (Vol. 67). http://doi.org/10.1016/S0304-405X(02)002520

Fraser, D. R., Zhang, H., \& Derashid, C. (2006). Capital structure and political patronage: The case of Malaysia. Journal of Banking and Finance, 30(4), 1291-1308. http://doi.org/10.1016/j.jbankfin.2005.05.008

Hirota, S. (1999). Are Corporate Financing Decisions Different in Japan? An Empirical Study on Capital Structure. Journal of the Japanese and International Economies, 13(3), 201-229. http://doi.org/10.1006/jjie.1999.0435

Iqbal, A., \& Kume, O. (2014). Impact of Financial Crisis on Firms' Capital Structure in UK, France, and Germany. Multinational Finance Journal, 18(3/4), 249-280. http://doi.org/10.17578/18-3/4-3

Jaros, J., \& Bartosova, V. (2015). To the Capital Structure Choice: Miller and Modigliani Model. Procedia Economics and Finance, 26(15), 351-358. http://doi.org/10.1016/S22125671(15)00864-3

Johnson, S., \& Mitton, T. (2003). Cronyism and capital controls: Evidence from Malaysia. Journal of Financial Economics, 67(2), 351-382. http://doi.org/10.1016/S0304405X(02)00255-6

Karpavičius, S., \& Yu, F. (2017). The impact of interest rates on firms' financing policies. Journal of Corporate Finance, 45, 262-293. http://doi.org/10.1016/j.jcorpfin.2017.05.007 
MANAGEMENT SCIENCES

Vol. 12, No. 1, 2022, E-ISSN: 2225-8329 ๔ 2022 HRMARS

Lee, J.-W., Lee, Y. S., \& Lee, B.-S. (2000). The Determination of Corporate Debt in Korea. Asian Economic Journal, 14(4), 333-356. http://doi.org/10.1111/1467-8381.t01-1-00113

Aswani, N. N. K., \& Pok, W. C. (2009). Capital Structure: A Comparison between Malaysian GLCs and Non-GLCs. In The Malaysian Finance Association 11th Annual Conference with theme Financial Market, Governance and Growth: Issues and Challenges. Bayview Beach Resort, Batu Ferringhi, Penang, Malaysia.

Pandey, I. M. (2001). Capital Structure and The Firm Characteristics:Evidence From an Emerging Market, 1-19.

Prema-chandra, A. (2010). Working Papers in Trade and Development: Malaysian Economy in Three Crises (No. 2010/12). Retrieved from https://crawford.anu.edu.au/acde/publications/publish/papers/wp2010/wp_econ_20 10_12.pdf

Shyam-Sunder, L., \& Myers, S. C. (1999). Testing static tradeoff against pecking order models of capital structure. Journal of Financial Economics, 51(2), 219-244. http://doi.org/10.1016/S0304-405X(98)00051-8

Suto, M. (2003). Capital Structure and Investment Behaviour of Malaysian Firms in the 1990s: A study of corporate governance before the crisis. Corporate Governance: An International Review, 11(1), 25-39. http://doi.org/10.1111/1467-8683.00299

Titman, S., \& Wessels, R. (1988). The Determinants of Capital Structure Choice. Journal of Finance, 63(1), 1-19.

Tong, G., \& Green, C. J. (2005). Pecking order or trade-off hypothesis? Evidence on the capital structure of Chinese companies. Applied Economics, 37(19), 2179-2189. http://doi.org/10.1080/00036840500319873

Trinh, T. H., \& Phuong, N. T. (2015). Effects of Financial Crisis on Capital Structure of Listed Firms in Vietnam. International Journal of Financial Research, 7(1), 66-74. http://doi.org/10.5430/ijfr.v7n1p66

Wiwattanakantang, Y. (1999). An empirical study on the determinants of the capital structure of Thai firms. Pacific-Basin Finance Journal, 7(3-4), 371-403. http://doi.org/10.1016/S0927-538X(99)00007-4

Zou, H., \& Xiao, J. Z. (2006). The financing behaviour of listed Chinese firms. British Accounting Review, 38(3), 239-258. http://doi.org/10.1016/j.bar.2006.04.008

Tselichtchev, I. S. (2007), Asia's Government-Linked Companies on Course to Becoming New Sources of Friction, JCER Staff Report, Japan Center for Economic Research, June 7, pp. $1-3$, available at: www.jcer.or.jp, accessed on 20th March 2008. 